\title{
薄鋼板の湾曲磁気浮上装置の検討
}

丸森 宏樹 ${ }^{* 1}$, 米澤 暉 ${ }^{* 1}$, 成田 正敬 ${ }^{* 2}$, 加藤 英晃 ${ }^{* 3}$, 押野谷 康雄 ${ }^{* 4}$

\section{Consideration on bent magnetic levitation apparatus for thin steel plate}

\author{
Hiroki MARUMORI ${ }^{* 1}$, Hikaru YONEZAWA ${ }^{* 1}$, Takayoshi NARITA ${ }^{* 2}$, \\ Hideaki KATO $^{* 3}$ and Yasuo OSHINOYA ${ }^{* 4}$ \\ ${ }^{* 1}$ Department of Mechanical Engineering, Tokai University \\ 4-1-1 Kitakaname, Hiratsuka-shi, Kanagawa 259-1292, Japan \\ ${ }^{* 2}$ Department of Electrical and Electronic Engineering, Tokyo University of Science, Suwa \\ 5000-1 Toyohira, Chino-shi, Nagano 391-0292, Japan \\ ${ }^{* 3, * 4}$ Department of Prime Mover Engineering, Tokai University \\ 4-1-1 Kitakaname, Hiratsuka-shi, Kanagawa 259-1292, Japan
}

\section{Received 19 September 2014}

\begin{abstract}
In the transport system of a thin steel plate production line, there is a problem that the quality of the plate surface deteriorates over time because the plate is usually in contact with rollers. Accordingly, studies of electromagnetic levitation technology have been carried out. However, when a flexible thin steel plate is targeted for levitation, levitation control becomes difficult because the thin plate undergoes increased flexure. To solve this problem, we proposed a levitation of a flexible thin steel plate that was bent to an extent which did not induce plastic deformation. Bent magnetic levitation apparatus was developed and bending levitation performance of thin steel plate was examined. Thin steel plates with a thickness of $0.18 \mathrm{~mm}, 0.24 \mathrm{~mm}$, $0.27 \mathrm{~mm}$ and $0.30 \mathrm{~mm}$ were levitated to evaluate the relationship between tilt angle of electromagnets and levitation probability. Furthermore, to elucidate the optimal tilt angle of electromagnets, shapes of steel plates were analyzed using finite difference method and effective tilt angle was estimated. As a result, levitation probability increased by bending a steel plate to the extent that did not exceed natural deflection angle. Also, the optimal tilt angle of electromagnets can be estimated by shape analysis result and matched the experimental result. In developing the bent magnetic levitation apparatus, the optimal tilt angle of electromagnets was verified.
\end{abstract}

Key words : Magnetic levitation, Vibration control, Optimal control, Thin steel plate, Bending levitation control

\section{1. 緒言}

リニア中央新幹線の営業運転の整備がはじまり磁気浮上技術はより身近なものになってきている．また輸送機 械の分野にとどまらず物体を非接触で把持・搬送できる磁気浮上技術は製鉄プロセスラインなどの工業の分野に おける応用も非常に期待されている。中でも摩擦損失の低減や表面品質の劣化防止という課題に対して注目が集 まり，磁気浮上技術の応用による非接触搬送に関する研究が活発になされている（Nakagawa, et al., 2000）

（Namerikawa, et al., 2006）（大路他，2011）（佐藤，鳥居，2008）。しかし磁気浮上技術に関する研究の多くは浮上 対象が剛体と考慮できる物体について検討されており，複雑な変形を起こす柔軟体の磁気浮上についての報告は 少ない.

当研究グループでは浮上が困難である薄鋼板に着目し, 電磁石による吸引力を用いた薄鋼板磁気浮上システム

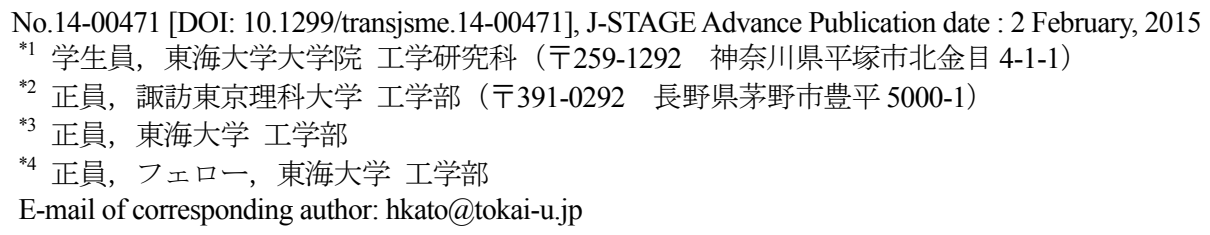



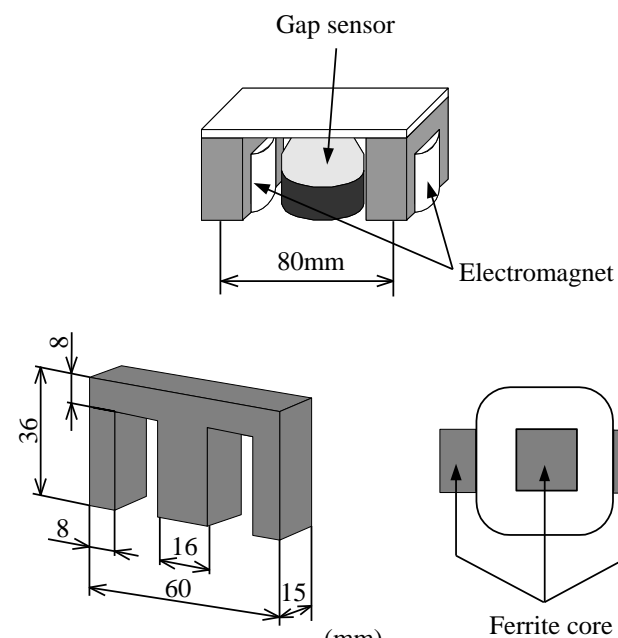

Ferrite core

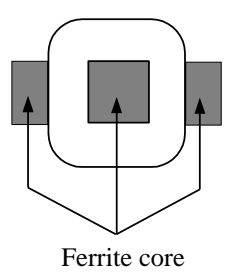

Electromagnet (Bottom view)

Fig. 1 Schematic illustration of electromagnet unit

について検討を行なってきている（押野谷，小林，1994）。薄鋼板を浮上させる場合，鋼板自体が変形することに より複雑な振動が発生し浮上制御は困難となる．そのため，これまでに鉛直方向から鋼板を吊り下げるように設 置した電磁石に加え, 鋼板端部のエッジ部分に設置した電磁石にて水平方向から張力を印加するシステムの開発 (押野谷他，2002）や電磁石の吸引力が及ばない範囲に永久磁石を設置する装置の提案（押野谷，石橋，2001） および永久磁石の最適な配置探索（成田他，2013）を行い浮上安定性の向上について継続的に検討してきた. し かしこれらの手法は装置や制御システムが複雑になるばかりでなく, 設備投資やランニングコストが増加すると いう課題もあった。

薄鋼板を浮上させる場合, 電磁石の吸引力が印加されない場所にたわみが生じるため, 限られた電磁石の個数 で鋼板を安定して浮上させることは困難であり，浮上中のたわみを抑制することが浮上安定性の向上につながる と考えられる，そこで本研究では浮上の障害となっていた薄鋼板の柔軟性を積極的に利用し，対象が塑性変形せ ず浮上終了後の材料特性に影響を与えない程度に湾曲させることで最小限の電磁石のみによって浮上させる磁気 浮上装置を提案する．先に述べた製鉄プロセスの搬送ラインでは，近年極めて薄い鋼板の製造も可能となり，多 岐にわたる需要から表面品質を劣化させずに浮上搬送させることが重要であるが，この課題に対する有効な対策 は講じられていない.

本論文で提案する電磁石に傾斜を設けることで鋼板を湾曲させる浮上システムを切板搬送ラインなどに適用す ることで, 数多くの電磁石を用いて高度な制御理論により高い浮上性能を実現する従来の手法よりも簡易かつ低 コストで製品の品質向上が期待できる．製鉄プロセスラインでは板厚やサイズの異なる鋼板を取り扱う必要があ るが，これらのパラメータに対する磁石配置と湾曲度合いの最適化を行うことで, 安定した湾曲磁気浮上システ ムを構筑することが可能となる. 本研究では切板の非接触搬送の基礎研究として, 四辺自由端の長方形薄鋼板を 曲げて浮上させる湾曲磁気浮上システムを検討する.

前述のとおり鋼板を湾曲浮上させる場合，その長さ，幅，厚さ，材質などを総合的に考慮して最適な電磁石の 設置位置や湾曲度合いを理論的に求める必要がある. 本論文ではその基礎検討として鋼板のサイズ（長さ，幅） が同一であり厚さのみが変化した場合を対象とする. なお検討の手法として有限差分法（FDM）を用い湾曲浮上 中の静たわみ解析を行う。これにより算出された鋼板形状から評価值を定義し, さらに鋼板を一自由度系として モデル化した浮上制御実験結果との比較を行い，本装置設計に対する基礎資料の提示を行う.

\section{2. 薄鋼板の湾曲浮上装置}

\section{$2 \cdot 1$ 電磁石ユニットの配置}

図 1 に電磁石ユニットの概略図を示寸. 電磁石ユニットは 2 つ電磁石と 1 つの渦電流式非接触変位センサか ら構成されている. 電磁石は $\mathrm{E}$ 型フェライトコアに直径 $0.5 \mathrm{~mm}$ のエナメル線を 1005 回巻いたものである. この 


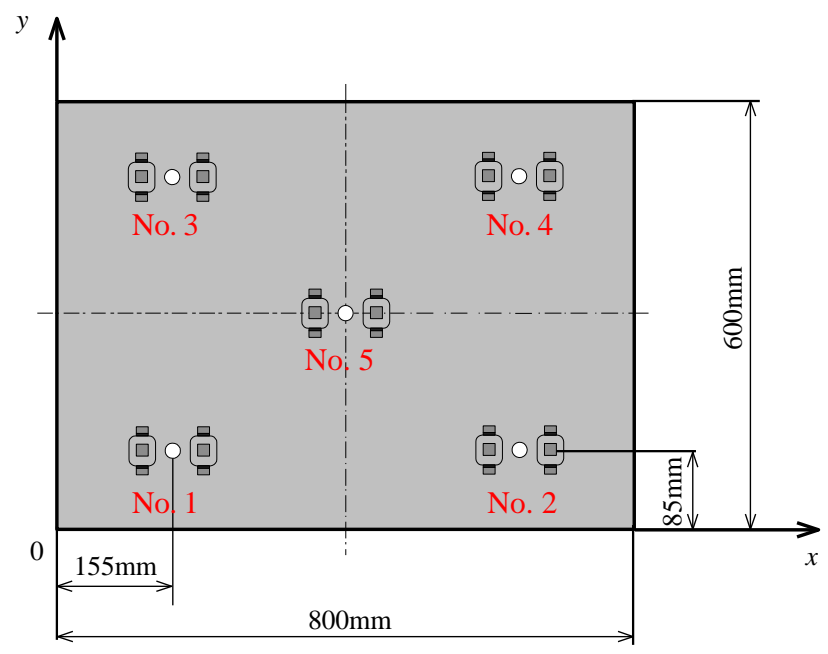

Fig. 2 Arrangement of electromagnets

電磁石の電気回路は直列結合されており，変位センサを中央に挟むように配置してある. なお電磁石の磁場によ る変位センサへの影響を計測した結果，測定誤差は $1 \%$ 以下であり制御系に及ぼす影響はほとんどないことを確 認している（押野谷他，1996）.

本研究では柔軟な長方形亜鉛めっき鋼板（材質 SS400, 長さ $a=800 \mathrm{~mm}$, 幅 $b=600 \mathrm{~mm}$ ）を浮上対象とする. 薄鋼板は柔軟連続体ゆえに限られた個数の電磁石では静的なたわみや高次モードの弾性振動を十分抑制すること ができず, 安定浮上は困難となる. 数多くの電磁石を利用すればこれらの問題が解決可能となるが，前述の通り コストやメンテナンスの面などから実用的でない，そこで鋼板を支持するのに最低限必要である 4 つの電磁石ユ ニットを周囲に配置する．さらに鋼板の重心部分を支持するように鋼板中央部に電磁石ユニットを設置し，合計 5 か所から鋼板を吊り下げるようにして非接触支持する.

図 2 に $x-y$ 平面における電磁石ユニットの設置位置を示す. 鋼板の自重と 5 つの電磁石ユニットに印加される 吸引力が釣り合うことで鋼板は浮上する. 本研究では周囲の電磁石ユニット（No.1４）の吸引力を増加させ，中 央の電磁石ユニット（No.5）の吸引力を低下させることで鋼板を湾曲浮上させる．そのため湾曲させる度合いが 大きくなるに伴い，鋼板中央の電磁石ユニットNo.5による支持力は小さくなり，No.1 4 の支持力が支配的とな る. よって $x$ 軸に見た電磁石位置は湾曲浮上させた際の安定性向上のため薄鋼板を電磁石ユニット No.1（もしく は No.2）とNo.3（もしくはNo.4）の 2 点で支持された両端突出単純支持はりとして考え，はり全体に生じる静 的たわみ量の総和が最小となる位置とした。 なお一様断面はりの断面二次モーメントは板の剛性と等価となるよ うにした．電磁石ユニットの吸引力は鋼板の面積に対して非常に狭い範囲に作用するため 1 点に力が加わると見 なし，各電磁石ユニットの中央部にてピン支持とした.

同様に $y$ 軸に見た電磁石位置は薄鋼板を電磁石ユニットNo.1（もしくはNo.3）と No.2（もしくは No.4）に加 え中央の電磁石ユニットN N . 5 の 3 点で支持された両端突出単純支持はりとして考える. 各電磁石ユニットでの支 持力が等しくなるように, 3 点支持された支持力の比が $2: 1: 2$ になる位置とした.

\section{$2 \cdot 2$ 電磁石ユニットの吸引カ}

鋼板を湾曲させた際の各電磁石ユニットに印加する吸引力については, 鋼板を $x$ 軸に見た場合のはりと見なし 算出した. 電磁石ユニットNo.1（もしくはNo.2）, No.5, No.3（もしくはNo.4）の 3 点で支持された両端突出単 純支持はりにおいて，外側の支持点 No.1〜No.4 におけるたわみ角 $\theta$, および中央の支持点 No.5 での支持力 $F_{5}$ の 関係は次式で表される.なお $F_{5}$ を求める(1)式は両端突出単純支持はりに等分布荷重が作用した場合と中央集中荷 重が作用した場合の重ね合わせにより求めた.

$$
F_{5}=\frac{2 a h}{3 l^{2}}\left\{\rho g l\left(l^{2}-6 d^{2}\right)-2 E h^{2} \theta\right\}
$$




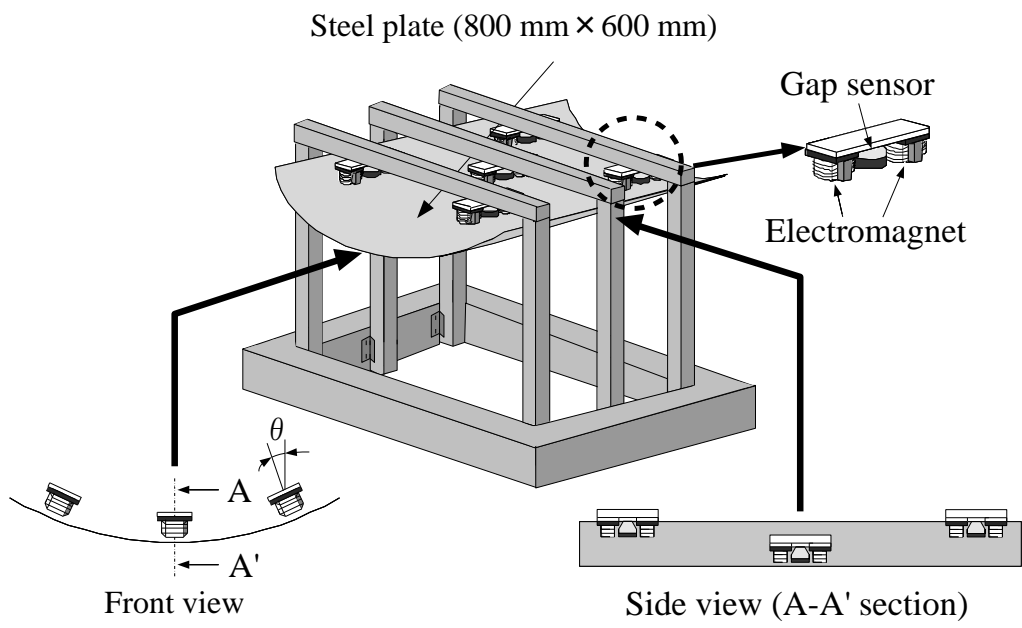

Fig. 3 Schematic illustration of experimental apparatus

また鋼板の質量より，外側の支持点No.1〜No.4 での支持力 $F_{1} \sim F_{4}$ は次式となる.

$$
F_{1}=F_{2}=F_{3}=F_{4}=\frac{\rho a h g b-F_{5}}{4}
$$

ここで, $h:$ 板厚 $[\mathrm{m}], \rho:$ 鋼板の密度 $\left[\mathrm{kg} / \mathrm{m}^{3}\right], g$ :重力加速度 $\left[\mathrm{m} / \mathrm{s}^{2}\right], l: x$ 軸に見た電磁石ユニット No.1 と No.3, あるいは No.2 と No.4の距離 $[\mathrm{m}], d: x$ 軸に見た電磁石ユニットNo.1，No.2，No.3，No.4から鋼板端部 までの距離 $[\mathrm{m}], E$ : 鋼板のヤング率 $\left[\mathrm{N} / \mathrm{m}^{2}\right]$ である. なお予備実験により，各電磁石ユニットにより発生する 支持力の実験值と計算值は誤差 $10 \%$ 以下であることを確認している.

さらに電磁石ユニットNo.5 の支持力 $F_{5}=0$ のとき, No.1 No.4のみで鋼板を支持した際の支持点におけるた わみ角を自然たわみ角 $\theta_{n a}$ と定義し，次式で表す（社団法人土木学会，1986）.

$$
\theta_{n a}=\frac{\rho g l}{2 E h^{2}}\left(l^{2}-6 d^{2}\right)
$$

\section{$2 \cdot 3$ 湾曲磁気浮上装置}

製作した湾曲磁気浮上装置の概略図を図 3，写真を図 4 に示寸．電磁石ユニット No.1〜4 は図 4 （b）のように 水平方向に移動させ, さらに電磁石の傾斜角 $\theta$ を調整できる機構とし, 傾斜角 $\theta$ で鋼板は湾曲するものとする. また薄鋼板の湾曲度合いに合わせて電磁石ユニットNo.5 は図 4 (c) のように上下方向に移動することができる. なお電磁石ユニットNo.1 4 の傾斜角 $\theta$ を変更しても鋼板に対し吸引力の作用する位置が一定になるように, 電 磁石ユニット No.1〜 4 は鋼板の自然なたわみ形状をもとに水平方向位置を調整する. 電磁石の傾斜角 $\theta$ に対する 鋼板形状を図 5 に示寸.

\section{3. 有限差分法を用いた薄鋼板のたわみ解析}

\section{$3 \cdot 1$ 解析モデル}

薄鋼板の安定浮上を実現するにあたり，最適な湾曲の度合いに関して検討する必要がある，そこで薄板全体を 面で支持した状態を理想的な鋼板形状と考え，理想形状と定義する．なお理想形状は鋼板を $x$ 軸に見た場合のは りと考え，一次元のはりのたわみ形状を鋼板サイズに押出したものとする.

鋼板を湾曲させた際の理想形状に対する総たわみ量を評価するために, 重力が作用する際の薄鋼板のたわみ量 を計算し, 湾曲浮上させた鋼板形状を算出寸る. 薄鋼板の静的なたわみの方程式は次式で示される. 


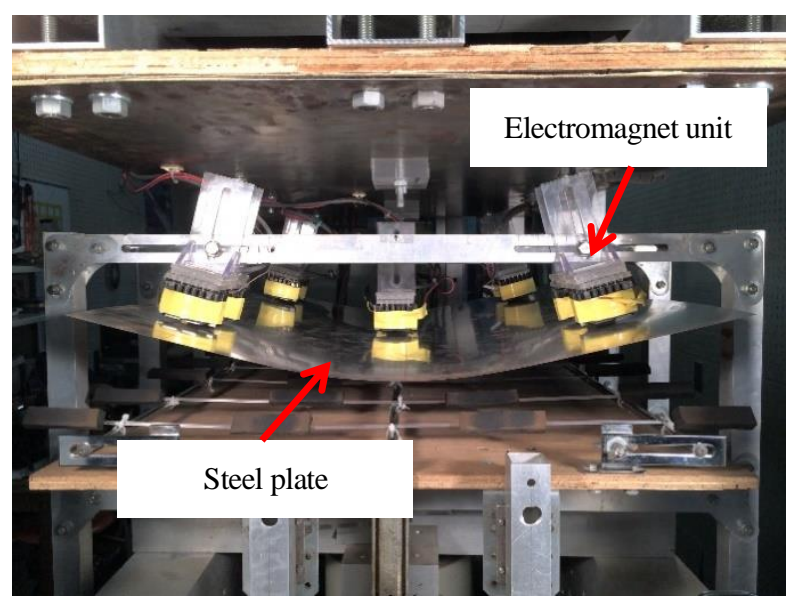

(a) Bent thin steel plate being levitated (Front view)

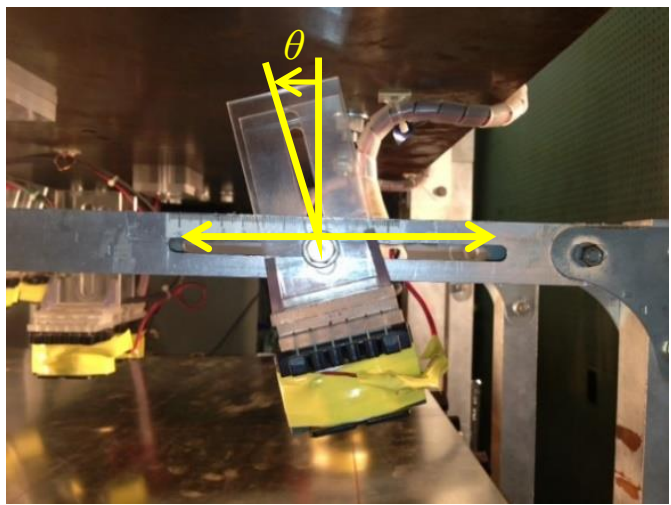

(b) Tilt angle and horizontal adjustment mechanism of electromagnets (Electromagnet unit No.1 4)

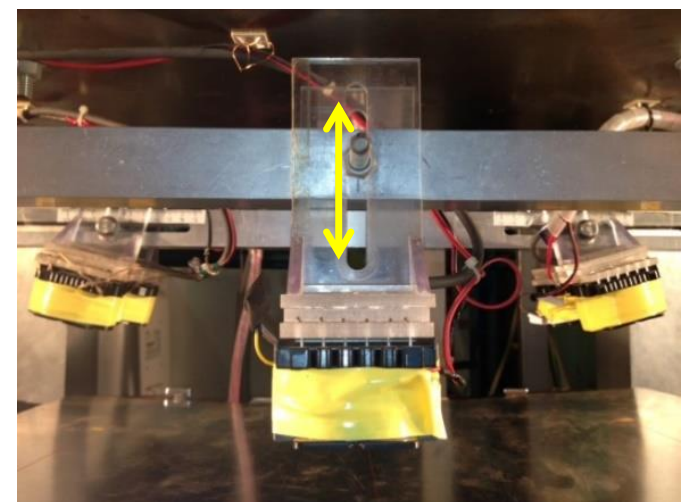

(c) Vertical adjustment mechanism of electromagnets (Electromagnet unit No.5)

Fig. 4 Photograph of experimental apparatus

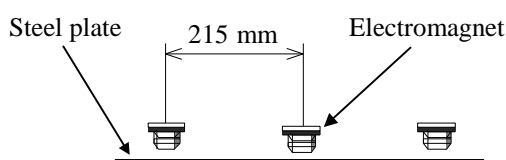

(a) $\theta=0^{\circ}$

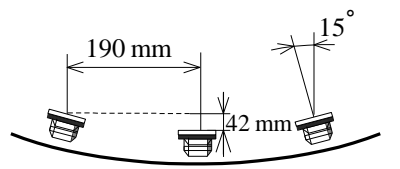

(d) $\theta=15^{\circ}$

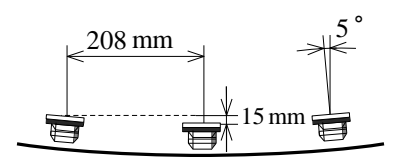

(b) $\theta=5^{\circ}$

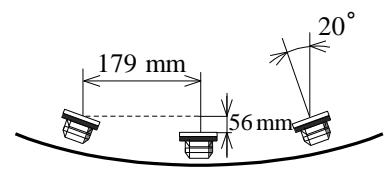

(e) $\theta=20^{\circ}$

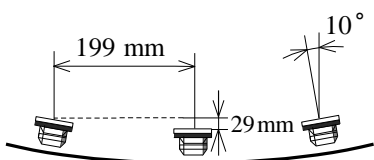

(c) $\theta=10^{\circ}$

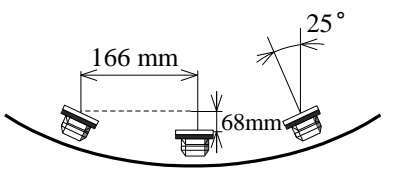

(f) $\theta=25^{\circ}$

Fig. 5 Relationship between tilt angle of electromagnets and shape of the steel plate

$$
\begin{aligned}
& D \nabla^{4} z=\rho g h-f \\
& D=\frac{E h^{3}}{12\left(1-v^{2}\right)} \quad \nabla^{4}=\frac{\partial^{4}}{\partial x^{4}}+2 \frac{\partial^{4}}{\partial x^{2} \partial y^{2}}+\frac{\partial^{4}}{\partial y^{4}}
\end{aligned}
$$


ここで $v:$ ポアソン比, $x$ : 薄鋼板の長手方向の座標 $[\mathrm{m}], y$ : 薄鋼板の短手方向の座標 $[\mathrm{m}], z$ : 薄鋼板の鉛直 方向変位 $[\mathrm{m}], f$ : 電磁石ユニット No.5により鉛直方向から薄鋼板に加わる単位面積あたりの吸引力 $\left[\mathrm{N} / \mathrm{m}^{2}\right]$ で ある.

薄鋼板は電磁石ユニット No.1〜 4 で単純支持するものとし, 式 (1) より No.1〜 4 における鋼板の曲げ角度が $\theta$ になるよう支持力 $F_{5}$ を算出する. 式 (1) より求めた $F_{5}$ が作用する鋼板部分は解析モデルにおける節点に分布荷 重として加わると仮定して $f$ を求めた．吸引力 $f$ を電磁石ユニット No.5 に作用させ，式 (4) を用いて薄鋼板の たわみを FDM によって計算する．このとき，差分解析格子の大きさは鋼板のたわみ形状が十分把握でき，かつ 計算時間を考慮し $10 \mathrm{~mm} \times 10 \mathrm{~mm}$ とした。 なお解析モデルおよび手法の妥当性については既報（成田他，2013） にて確認している.

\section{$3 \cdot 2$ 解析結果と評価值}

解析結果の一例として長さ $a=800 \mathrm{~mm}$, 幅 $b=600 \mathrm{~mm}$, 板厚 $h=0.20 \mathrm{~mm}, 0.16 \mathrm{~mm}, 0.13 \mathrm{~mm}$ の薄鋼板に対し, 電磁石ユニット No.1〜 4 の電磁石位置における鋼板の曲げ角度が $10^{\circ}$ になるように $f$ を入力した鋼板形状を図 6 (a)，（b)，（c）に示寸．ここで，図 6 （d）は鋼板の曲げ角度が $10^{\circ}$ における $x$ 軸方向のたわみを拘束した理想 形状である．なお各図の右上には理想形状に対する鋼板のたわみ量を示している．ここで理想形状に対する総た わみ量を評価するために評価值 $j$ を次式のように定義した.

$$
j=\frac{\sum_{i=1}^{N}\left|z_{i}-z_{0}\right|}{h \cdot N}
$$

$z_{i}$ : 薄鋼板の各解析点における $z$ 成分の変位 $[\mathrm{m}], z_{0}$ : 理想形状の $z$ 成分の変位 $[\mathrm{m}], N$ : 解析点の総数 $\quad(N=4941)$ である.

図 6 より板厚が薄くなる程たわみ量が増え理想形状からの総たわみ量が大きくなり, 評価值 $j$ も増えているこ とが分かる. 同じ鋼板の曲げ角度 $10^{\circ}$ において板厚が変化すると浮上特性も変化すると考えられるが，次章では 実験と $j$ を比較し, $j$ による最適な電磁石の曲げ角度について考察していく.

\section{4. 薄鋼板の湾曲浮上システム}

\section{$4 \cdot 1$ 制御装置}

制御システムの概略を図 7 に示寸. 薄鋼板を 5 か所の電磁石ユニット（No.1～5）により吊り下げるようにして 非接触支持するために，鋼板の変位を 5 個の渦電流式非接触変位計により検出する. また検出した変位をディジ タル微分により速度に変換する. さらに電磁石コイル電流を測定用の外部抵抗より検出し, 合計 15 個の観測值を A/D コンバータから DSP に入力し制御則を計算する. D/A コンバータから電流供給用アンプヘ制御電圧を出力し, 5 個の電磁石吸引力を制御し，鋼板を電磁石表面から $5 \mathrm{~mm}$ の位置に磁気浮上させる.

\section{$4 \cdot 2$ 鋼板のモデル化}

本論文では鋼板のモデル化として設計が簡易な一自由度モデルを適用する（Hasegawa, et al., 2006）。一自由度モ デルでは各電磁石ユニットで検出した変位, 速度, 電磁石コイル電流值をその電磁石ユニットに対してのみフィ ードバック制御を行う。そこで図 8 に示すように鋼板を 5 つの仮想質量に分割し, それぞれを集中定数系として モデル化する.

電磁石ユニットからの静的吸引力によって鋼板を支持すれば一定の距離に保たれる平衡状態 $Z_{0}$ が存在する. そ こからの鉛直方向の変位を $z_{n}$ とすると, 運動方程式は以下のようになる. なおすべての記号において添え字 $n$ は電磁石ユニットの No.1〜 5 を示す $(n=1 \sim 5)$.

$$
m_{n} \ddot{z}_{n}=2 f_{n}
$$


Marumori, Yonezawa, Narita, Kato and Oshinoya, Transactions of the JSME (in Japanese), Vol.81, No.823 (2015)

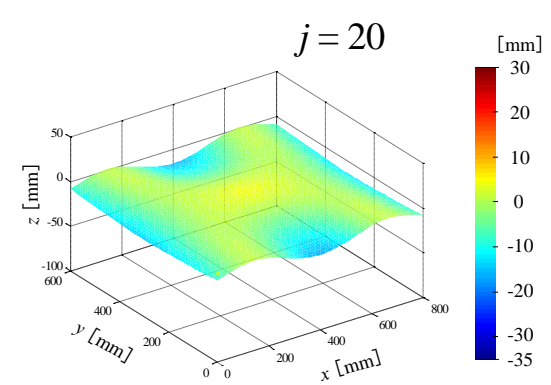

Flexure difference attained from optimal shape

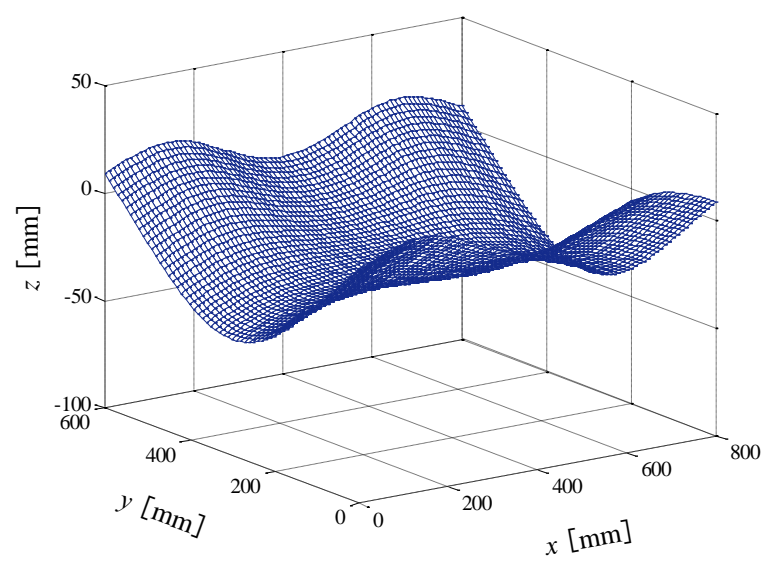

(a) $h=0.20 \mathrm{~mm}$

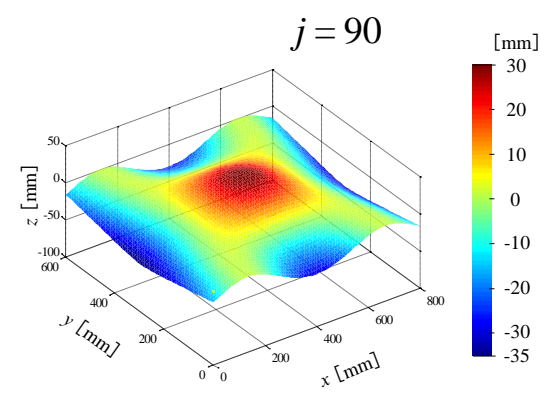

Flexure difference attained from optimal shape

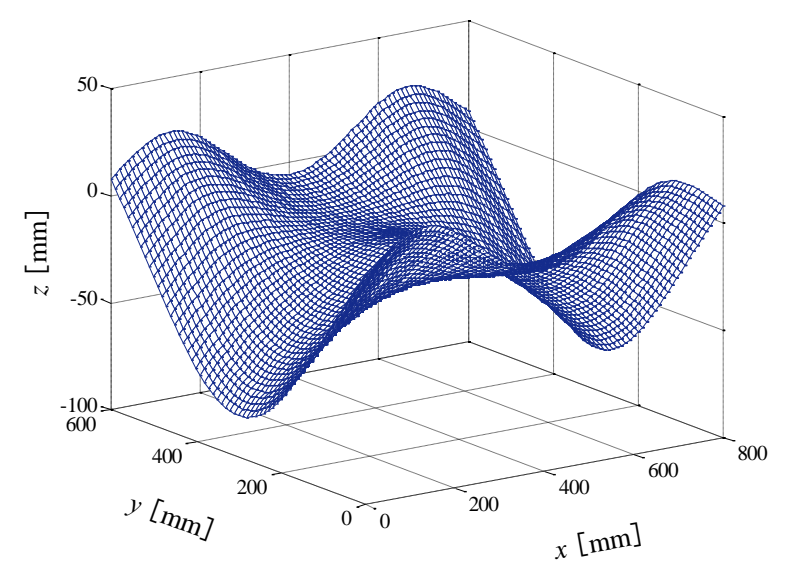

(c) $h=0.13 \mathrm{~mm}$

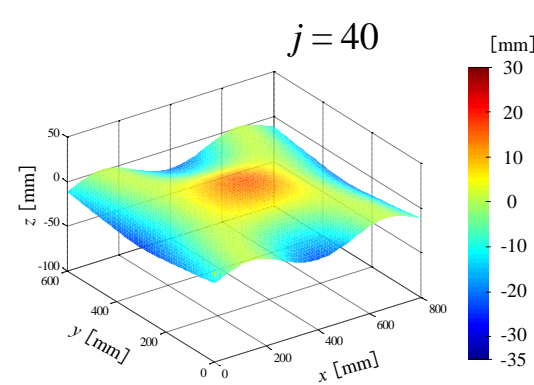

Flexure difference attained from optimal shape

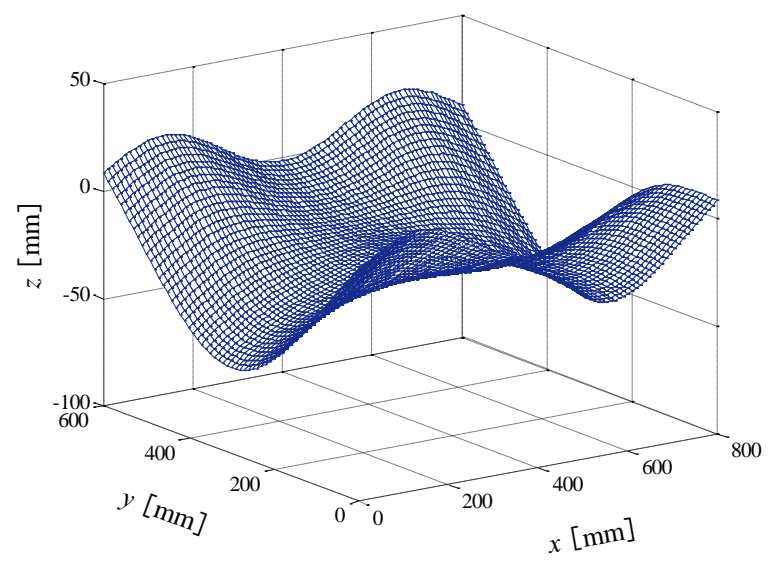

(b) $h=0.16 \mathrm{~mm}$

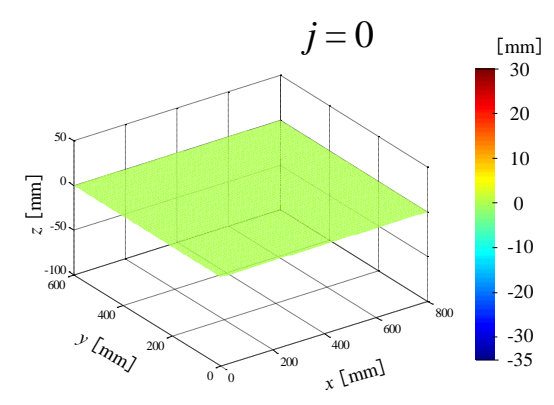

Flexure difference attained from optimal shape

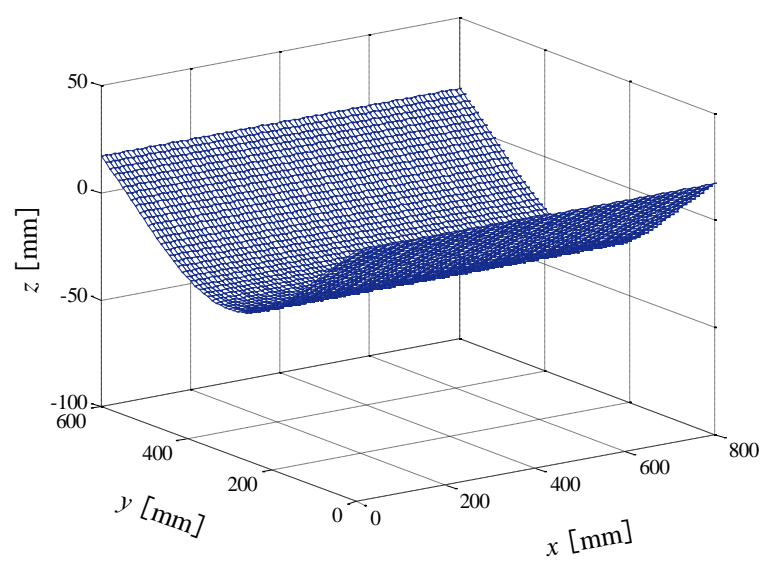

(d) Optimal shape

Fig. 6 Shape analysis of steel plate $\left(\theta=10^{\circ}\right)$ 


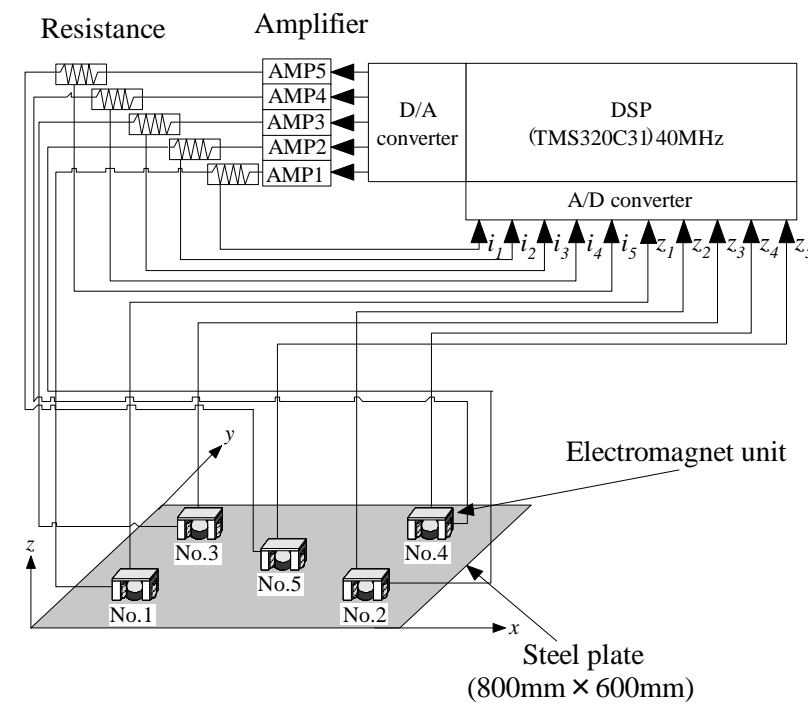

Fig. 7 Electromagnetic levitation control system

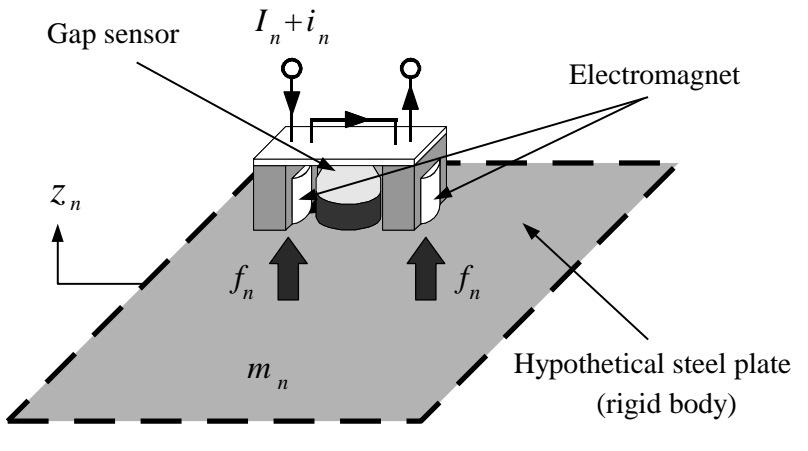

Fig. 8 Theoretical model of levitation control

ここで $m_{n}:$ 鋼板質量 $m$ を仮想的に 5 分割した質量 $[\mathrm{kg}], f_{n}$ : 電磁石 1 個あたりの吸引力の変動值 $[\mathrm{N}]$ であ る. 線形化近似を行った電磁石の吸引力および電磁石コイルに流れる電流に関する方程式は以下のようになる.

$$
\begin{aligned}
& f_{n}=\frac{F_{n}}{Z_{0}} z_{n}+\frac{F_{n}}{I_{n}} i_{n} \\
& \frac{d}{d t} i_{n}=-\frac{L_{e f f} I_{z}}{L_{n} Z_{0}^{2}} \frac{d}{d t} z_{n}-\frac{R_{n}}{2 L_{n}} i_{n}+\frac{1}{2 L_{n}} v_{n}
\end{aligned}
$$

電磁石コイルのインダクタンスは鋼板表面と電磁石表面との距離に反比例する成分と磁束の漏れに相当する成分 の和で表すことが一般に知られている（社団法人日本機械学会, 1995)。 そこで平衡浮上状態における電磁石 1 個当たりのコイルのインダクタンス $L_{n} \quad[\mathrm{H}]$ を以下のように表す.

$$
L_{n}=\frac{L_{e f f}}{Z_{0}}+L_{l e a}
$$

ここで $F_{n}$ : 各電磁石ユニットの 2 個の電磁石から発生する定常的な吸引力 $[\mathrm{N}], Z_{0}:$ 平衡状態における電磁 石ユニット表面と鋼板表面との距離 $[\mathrm{m}], I_{n}$ : 平衡状態における定常的な電磁石コイルの電流 $[\mathrm{A}], i_{n}: I_{n}$ か らの変動值 $[\mathrm{A}], L_{n}$ : 平衡状態における電磁石コイル 1 個あたりのインダクタンス $[\mathrm{H}], R_{n}$ : 電磁石ユニッ 卜の抵抗值 $[\Omega], \quad v_{n}$ : 電磁石コイルの定常電圧からの変動值 $[\mathrm{V}], L_{\text {eff }}$ : 電磁石 1 個あたりの鋼板へ有効に作 用するインダクタンス $[\mathrm{Hm}], L_{l e a}$ : 電磁石 1 個あたりの漏れ磁束 $[\mathrm{H}]$ である.

また図 3 の Front viewにて示した通り, 周囲の電磁石を傾け, 鋼板のたわみ形状に合わせて中央の電磁石の位 置を調節することにより鋼板を湾曲させるため, 鋼板の湾曲形状にかかわらず電磁石吸引力は鋼板に対して常に 垂直に作用寸る．従って鋼板を湾曲させた際のモデル化についても近似的に一自由度系としてモデル化を行う.

\section{$4 \cdot 3$ 制御系設計}

状態変数として鋼板の変位 $z_{n}$, 速度 $\dot{z}_{n}$ および電流 $i_{n}$ を採用し, 式（6）～（9）を整理して以下のような状 態方程式を得る. 
Table 1 Natural deflection angle

\begin{tabular}{c|c}
\hline \hline $\begin{array}{c}\text { Plate thickness } \\
h[\mathrm{~mm}]\end{array}$ & $\begin{array}{c}\text { Natural deflection angle } \\
\theta_{n a}\left[^{\circ}\right]\end{array}$ \\
\hline 0.18 & 19.2 \\
\hline 0.24 & 10.8 \\
\hline 0.27 & 8.5 \\
\hline 0.30 & 6.9 \\
\hline
\end{tabular}

$$
\dot{z}_{n}=A_{n} z_{n}+B_{n} \mathrm{v}_{n}
$$

$$
z_{\boldsymbol{n}}=\left[\begin{array}{lll}
z_{n} & \dot{z}_{n} & i_{n}
\end{array}\right]^{\mathrm{T}}, \quad \boldsymbol{A}_{\boldsymbol{n}}=\left[\begin{array}{ccc}
0 & 1 & 0 \\
\frac{2 F_{n}}{m_{n} Z_{0}} & 0 & \frac{2 F_{n}}{m_{n} I_{n}} \\
0 & -\frac{L_{e f f} I_{n}}{L_{n} Z_{0}^{2}} & -\frac{R_{n}}{2 L_{n}}
\end{array}\right], \quad \boldsymbol{B}_{\boldsymbol{n}}=\left[\begin{array}{lll}
0 & 0 & \frac{1}{2 L_{n}}
\end{array}\right]^{\mathrm{T}}
$$

制御系を離散時間系で構成するため, 離散時間系の最適制御理論に基づいて最適制御則を求める. 離散時間系 の評価関数は次のように表される.

$$
J=\sum_{k=0}^{\infty}\left[z_{\boldsymbol{n}}(k)^{\mathrm{T}} \boldsymbol{Q}_{\boldsymbol{n}} \boldsymbol{z}_{\boldsymbol{n}}(k)+r_{n} v_{n}(k)^{2}\right]
$$

ここで $Q_{n}$ : 変位 $z_{n}$, 速度 $\dot{z}_{n}$ および電流 $i_{n}$ に関する重み係数を要素とする行列, $r_{n}:$ 制御入力に関する重夕係 数である. $J$ を最小にするよう制御則を決定した.

\section{5. 湾曲浮上実験}

\section{$5 \cdot 1$ 実験方法}

浮上対象として市場で流通しており薄く柔軟な $h=0.18 \mathrm{~mm}, 0.24 \mathrm{~mm}, 0.27 \mathrm{~mm}, 0.30 \mathrm{~mm}$ の鋼板を使用し，電 磁石の傾斜角 $\theta$ による浮上性能について検討する. ここで $2 \cdot 1$ 節にて示した各板厚の自然たわみ角 $\theta_{n a}$ は表 1 の 通りである. 電磁石の傾斜角 $\theta$ は前掲図 5 のように $0^{\circ}$ から $25^{\circ}$ まで基本的に $5^{\circ}$ ごとに变更し，特に特性の確 認が必要な場合は任意の角度に設定して浮上実験を行う。各電磁石角度に対して 50 回浮上実験を行い，30 秒以 上浮上する場合を浮上成功として浮上確率を百分率で表す。なお 30 秒間浮上する場合は実用上問題とならない 10 分以上浮上継続が可能であることを予備実験により確認している. 重み係数は試行錯誤的に探索し, 板厚ごと に $\theta=0^{\circ}$ の変位標準偏差が等しくなるものを採用した. 本研究における各パラメータの值を表 2,3 に示す.

\section{$5 \cdot 2$ 電磁石の傾斜角 $\boldsymbol{\theta}$ に対する浮上性能}

図 9 に板厚 $h=0.18 \mathrm{~mm}, 0.24 \mathrm{~mm}, 0.27 \mathrm{~mm}, 0.30 \mathrm{~mm}$ における浮上確率の結果を示す. 横軸は電磁石の傾斜角 $\theta$ である. 図 9 には表 1 にて示した自然たわみ角 $\theta_{n a}$ を破線で示した. 本検討において最も薄い鋼板である（a） $h$ $=0.18 \mathrm{~mm}$ に着目すると $\theta=0^{\circ}$ での浮上確率は $58 \%$ であったが， $\theta$ の増加に伴い浮上確率は増加し， $\theta=15^{\circ}$ で 最大の $98 \%$ となった. さらに自然たわみ角 $\theta_{n a}=19.2^{\circ}$ よりも $\theta$ を大きくすると浮上確率は低下していき $\theta=25^{\circ}$ で $0 \%$ （浮上不可能）となった. 
Table 2 Parameters and values

\begin{tabular}{c|c}
\hline \hline Parameter & Value \\
\hline$\rho$ & $7500 \mathrm{~kg} / \mathrm{m}^{3}$ \\
\hline$l$ & $0.43 \mathrm{~m}$ \\
\hline$d$ & $0.085 \mathrm{~m}$ \\
\hline$E$ & $206 \mathrm{GPa}$ \\
\hline$v$ & 0.3 \\
\hline$Z_{0}$ & $5 \times 10^{-3} \mathrm{~m}$ \\
\hline$R_{n}$ & $21.0 \Omega$ \\
\hline$L_{\text {eff }}$ & $2.55 \times 10^{-4} \mathrm{Hm}$ \\
\hline$L_{\text {lea }}$ & $0.090 \mathrm{H}$ \\
\hline
\end{tabular}

Table 3 Weighting coefficients

\begin{tabular}{c|c}
\hline \hline Parameter & Value \\
\hline $\boldsymbol{Q}_{\boldsymbol{n}}(h=0.18 \mathrm{~mm})$ & $\operatorname{diag}\left(7.2 \times 10^{4}, 1.0 \times 10^{-1}, 2.0 \times 10^{0}\right)$ \\
\hline$r_{n}(h=0.18 \mathrm{~mm})$ & $2.9 \times 10^{-3}$ \\
\hline $\boldsymbol{Q}_{\boldsymbol{n}}(h=0.24 \mathrm{~mm})$ & $\operatorname{diag}\left(1.5 \times 10^{5}, 5.0 \times 10^{-2}, 1.0 \times 10^{2}\right)$ \\
\hline$r_{n}(h=0.24 \mathrm{~mm})$ & $1.0 \times 10^{-1}$ \\
\hline $\boldsymbol{Q}_{n}(h=0.27 \mathrm{~mm})$ & $\operatorname{diag}\left(1.5 \times 10^{5}, 5.0 \times 10^{-2}, 5.5 \times 10^{1}\right)$ \\
\hline$r_{n}(h=0.27 \mathrm{~mm})$ & $1.0 \times 10^{-1}$ \\
\hline $\boldsymbol{Q}_{n}(h=0.30 \mathrm{~mm})$ & $\operatorname{diag}\left(1.4 \times 10^{5}, 1.0 \times 10^{-1}, 2.0 \times 10^{0}\right)$ \\
\hline$r_{n}(h=0.30 \mathrm{~mm})$ & $1.5 \times 10^{-1}$ \\
\hline
\end{tabular}

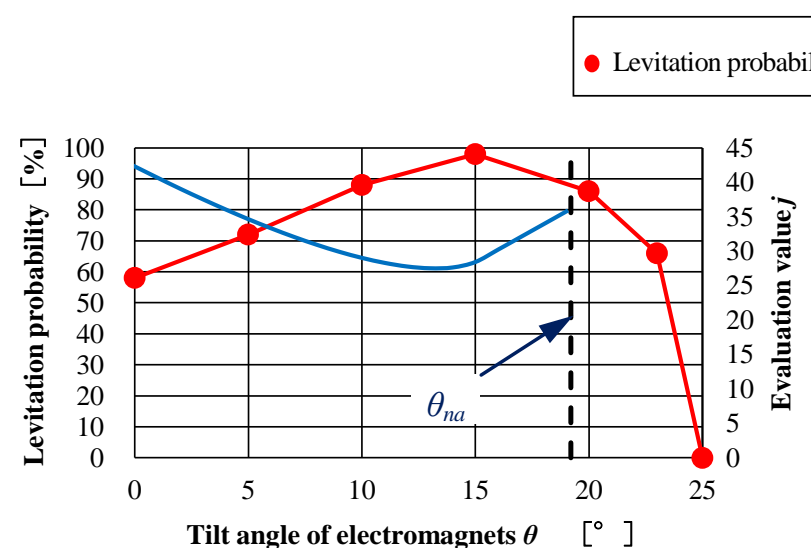

(a) $h=0.18 \mathrm{~mm}$

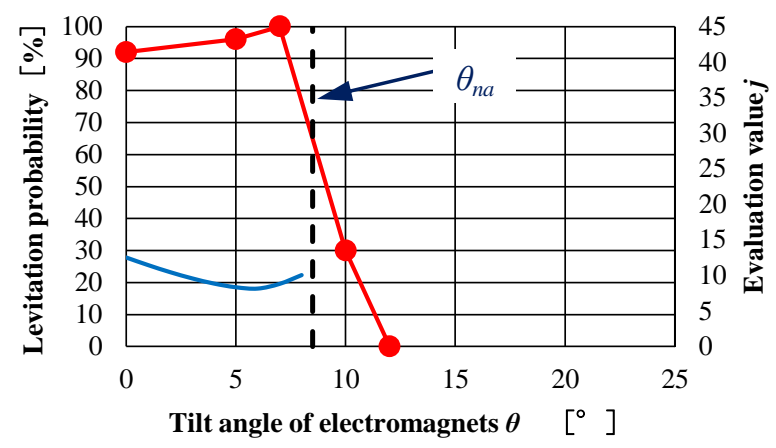

(c) $h=0.27 \mathrm{~mm}$

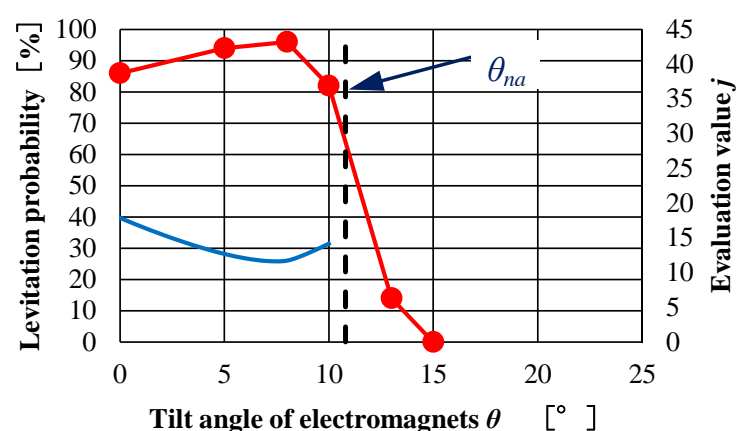

(b) $h=0.24 \mathrm{~mm}$

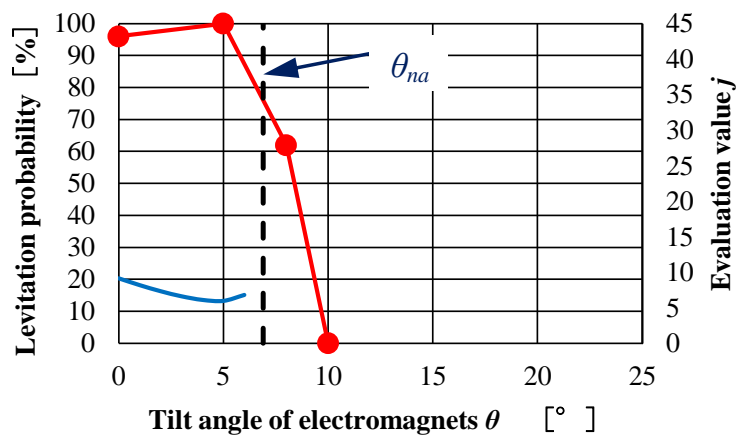

(d) $h=0.30 \mathrm{~mm}$

Fig. 9 Relationship between tilt angle of electromagnets $\theta$, levitation probability and evaluation value $j$

ここで図 $10(\mathrm{a}) \sim(\mathrm{c})$ に $h=0.18 \mathrm{~mm}$ の鋼板を $\theta=0^{\circ} ， 15^{\circ} ， 23^{\circ}$ で浮上させた際の時刻歴波形と振幅スペ クトルの一例を示す. なお各波形は電磁石ユニットNo.1のものであり，他の電磁石ユニットにおいても同じ傾向 を示すことを確認している.また時刻歴波形の縦軸の0は鋼板と電磁石表面との距離が $5 \mathrm{~mm}$ の位置に相当する. ここでこれらの応答が比較的不規則な性質を有していることから標準偏差にて評価を行う．標準偏差は 8 秒間の 時刻歴応答より算出しており，その際過渡状態の影響を除くため浮上から約 10 秒後に測定を開始した. それぞれ の傾斜角で 10 回ずつ測定した変位標準偏差の平均值は $\theta=0^{\circ} \quad$ が $0.040 \mathrm{~mm}, \theta=15^{\circ}$ が $0.038 \mathrm{~mm}, \theta=23^{\circ}$ が 0.062 $\mathrm{mm}$ であり, 浮上確率が最大となる $\theta=15^{\circ}$ が最も振動が抑制されていることが確認できる.また振幅スペクト 

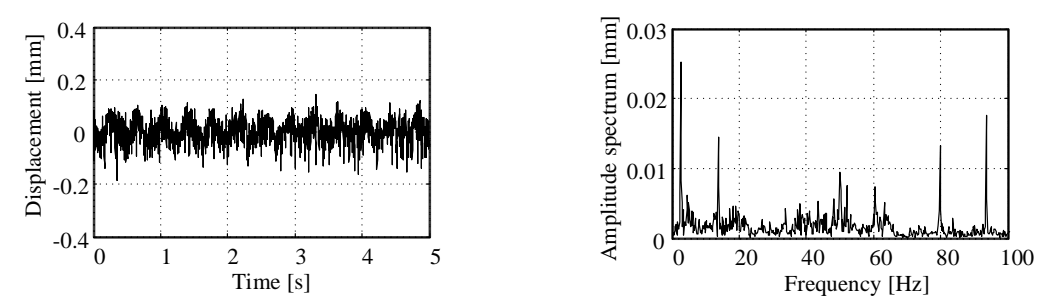

(a) $\theta=0^{\circ} \quad$ (Standard deviation of displacement $\left.=0.040 \mathrm{~mm}\right)$
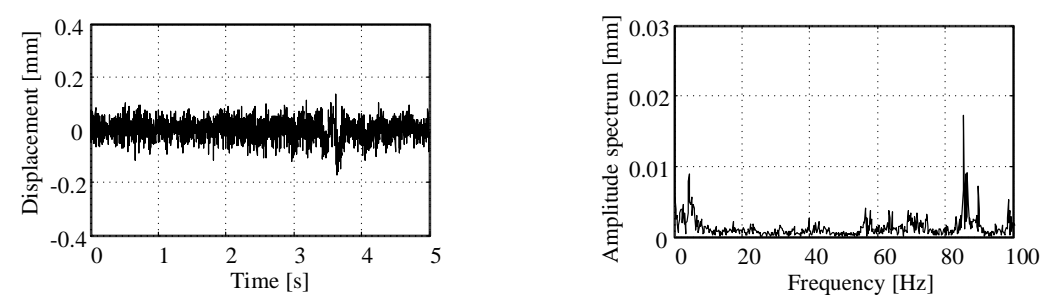

(b) $\theta=15^{\circ}$ (Standard deviation of displacement $\left.=0.038 \mathrm{~mm}\right)$
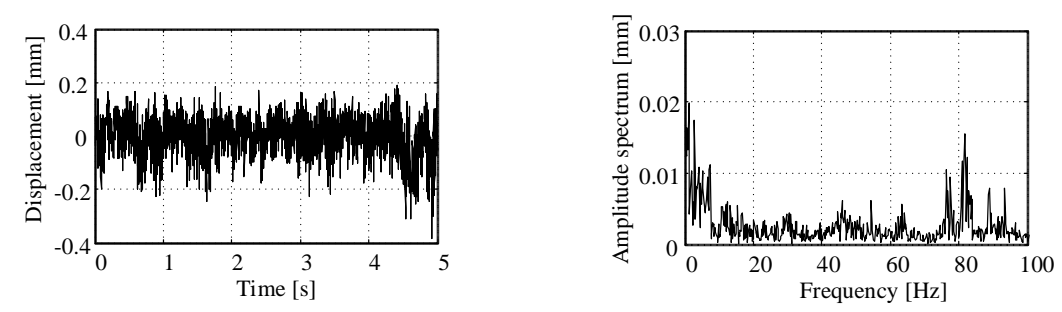

(c) $\theta=23^{\circ}$ (Standard deviation of displacement $\left.=0.062 \mathrm{~mm}\right)$

Fig. 10 Time histories and amplitude spectrums $(h=0.18 \mathrm{~mm})$

ルに着目すると $\theta=0^{\circ}$ では $3 \mathrm{~Hz}, 14 \mathrm{~Hz}, 80 \mathrm{~Hz}, 94 \mathrm{~Hz}$ などの周波数が卓越していることを確認できるが， $\theta=15^{\circ}$ ではそ れらの振動が抑制されており, これにより浮上性能が向上したと考えられる. なお $\theta=15^{\circ}$ においても $80 \mathrm{~Hz}$ 付近の振動が 発生しているがこれは鋼板 $x$ 軸方向の鋼板端部から電磁石ユニットまでの領域の弾性振動によるものであることを確認し ている.さらに自然たわみ角 $\theta_{n a}$ よりも鋼板を湾曲させた $\theta=23^{\circ}$ では $10 \mathrm{~Hz}$ 以下の振動か顕著に表れ，これにより浮上確 率が低下したと考えられる. 図9 (b) 〜 (d) に示した浮上結果より, 板厚の大きい鋼板を使用した浮上においても同様に, 電磁石の傾斜角 $\theta$ が $\theta_{n a}$ を超えない程度に設定して鋼板を浮上させることにより， $\theta=0^{\circ}$ よりも浮上確率が向上した.

\section{$5 \cdot 3$ 浮上確率と評価值 $j$}

各板厚における評価值 $j$ を図 9 に青い線で示す．傾斜角 $\theta$ の増加にともない評価值 $j$ は減少している. また $\theta$ が $\theta_{n a}$ より大きくなり浮上確率が低下寸る場合でも $j$ は増加していることが分かる．前述の通り $j$ はその值が低く なるほど，理想形状からのたわみ量の総和が小さいことを表しているが，理想形状により近くなるような電磁石 の傾斜角度であれば鋼板の各部分でのたわみが減少し，振動が抑制されることから浮上確率は高くなる.

ここで浮上確率が最も高くなる電磁石の傾斜角 $\theta$ と解析より評価值 $j$ が最小となる電磁石の傾斜角 $\theta$ を整理し 図 11 に示寸. 板厚 $h=0.18 \mathrm{~mm}, 0.24 \mathrm{~mm}, 0.27 \mathrm{~mm}, 0.30 \mathrm{~mm}$ の実験により浮上性能が最も良かった $\theta$ と解析に よる評価は概ね一致し, 評価值 $j$ が最小となる電磁石の傾斜角 $\theta$ で鋼板を浮上させることにより, 安定した浮上 状態を実現できることが確認できた. 本論文では比較検討を行う都合上 $\theta=0^{\circ}$ の振動がどの板厚でも同等になる ような重み係数を採用しているが，上記で得られた最適な傾斜角 $\theta$ において最高性能となる重み係数を求めれば 本論文のように比較的簡単なシステムであっても浮上確率が 100 \%となり実用上問題無いといえる. 
- Maximum of levitation probability

$\Delta$ Minimum of evaluation value $j$

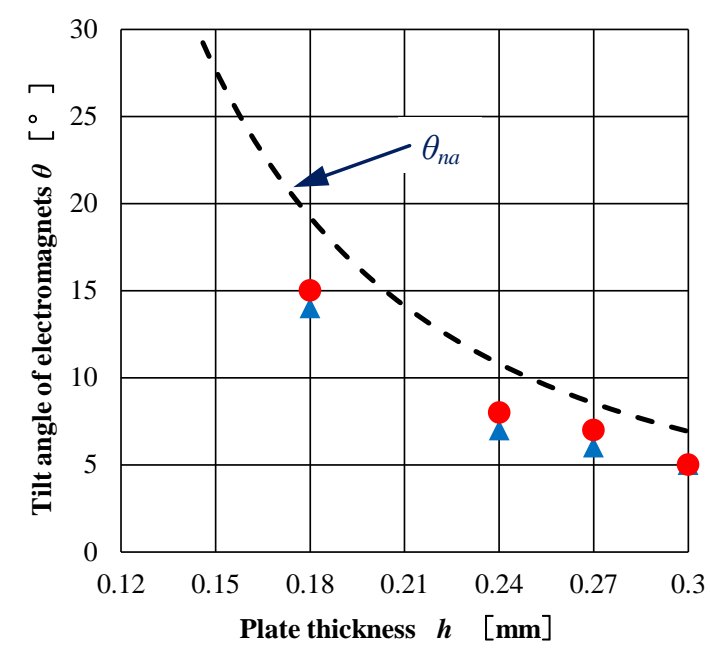

Fig.11 Relationship between plate thickness $h$ and optimal tilt angle of electromagnets $\theta$

\section{6. 結 言}

本研究では対象が塑性変形しない程度に薄鋼板を湾曲させることで最小限の電磁石のみにて安定した磁気浮上 を可能とする装置の提案を行った，薄鋼板を湾曲浮上させる場合，サイズや材質などを総合的に考慮して最適な 電磁石の設置位置や湾曲度合いを決定する必要がある，本論文ではその基礎検討として長さ，幅が一定であり， 厚さの異なる薄鋼板を対象とし静たわみ解析と鋼板を一自由度系としてモデル化した浮上制御実験から最適な鋼 板の湾曲度合いに関して考察を行った．本研究で得られた結論は以下の通りである.

(1) 従来のように湾曲させずに鋼板を浮上させた場合では薄い板厚であるほど浮上安定性は低下寸る傾向に あるが，本論文で提案した湾曲磁気浮上システムではこのようなより薄い厚さの鋼板に対して極めて高い 効果を発揮することが分かった.

（2）FDM を用いた静たわ久解析の結果から，5つの電磁石ユニットで鋼板を支持した場合にその吸引力が及ば ない範囲のたわみを最も抑制できる鋼板の湾曲度合いが推定できた.さらに，このときの湾曲度合いにて 浮上制御実験を行うと振動は抑制され，浮上性能が向上寸ることを確認した.

(3) 各板厚において鋼板の自然たわみ角を超えない程度の湾曲度合いであれば安定した浮上が実現できるこ とを実験的に示した．これにより薄鋼板の厚さが変化した場合でも簡易的に最適な湾曲度合いを推定する ことが可能となった.

今後は鋼板の挙動を厳密にモデル化した場合やロバスト性を有する制御理論を適用した場合の性能についても 検討を行っていく，さらに，各種薄鋼板に対する最適な電磁石の設置をリニアモータなどのアクチュエータを用 いて自動的に行う位置決め制御の実現も行う。

\section{文献}

Hasegawa, S., Oshinoya, Y. and Ishibashi, K., Consideration on Elastic Vibration Control of a Magnetically Levitated Thin Steel Plate Using Sliding Mode Control, JSME international journal, Series C, Vol.49, No.4 (2006), pp.983-993.

Nakagawa, T., Hama, M. and Furukawa, T., Study of magnetic levitation technique applied to steel plate production line, Transactions of the IEEE on magnetics, Vol.36, No.5 (2000), pp.3686-3689.

Namerikawa, T., Mizutani, D. and Kuroki, S., Robust Hœ DIA control of levitated steel plates, IEEJ Transactions on Industry Applications, Vol.126, No.10 (2006), pp.1319-1324.

成田正敬, 長谷川真也, 押野谷康雄, 永久磁石を聿いた薄鋼板のハイブリッド磁気浮上システム, Journal of the 
Magnetics Society of Japan, Vol.37, No.2 (2013), pp.29-34.

大路貴久, 苗真, 高見典幸, 飴井賢治, 作井正昭, 交流アンペール式リニア誘導浮上搬送装置の磁極配置と $\mathrm{Al}$ 薄板 の浮上特性, 日本 AEM 学会誌, Vol.19, No.3 (2011), pp.550-556.

押野谷康雄, 石橋一久, 長方形薄鋼板の磁気浮上制御装置の開発，日本機械学会論文集 C 編, Vol.67, No.661 (2001), pp.2855-2862.

押野谷康雄，小林学，周辺自由板の非接触支持制御，日本機械学会第 71 期通常総会講演論文集 (1994), pp.578-580.

押野谷康雄, 石橋一久, 関原孝宣, 磁気浮上長方形薄鋼板の搬送制御（弾性振動を抑制した鋼板の水平方向慣性力 に対する非接触制御機構の提案），日本機械学会論文集 C 編, Vol.68, No.669 (2002), pp.1428-1434.

押野谷康雄, 小林学, 丹野謙一, 相対する二辺が梁で補強された長方形薄鋼板の磁気浮上最適制御, 日本機械学会 論文集 C 編, Vol.62, No.600 (1996), pp.3067-3073.

佐藤公彦, 鳥居肃, リアルタイム振動解析手法を用いた薄鋼板センサレス支持制御, 電気学会論文誌 D, Vol.128, No.3 (2008), pp.267-273.

社団法人士木学会, 構造力学公式集(1986), p.156.

社団法人日本機械学会, 新技術融合シリーズ第一巻磁気軸受の基礎と応用(1995), pp.24-29.

\section{References}

Hasegawa, S., Oshinoya, Y. and Ishibashi, K., Consideration on Elastic Vibration Control of a Magnetically Levitated Thin Steel Plate Using Sliding Mode Control, JSME international journal, Series C, Vol.49, No.4 (2006), pp.983-993.

Nakagawa, T., Hama, M. and Furukawa, T., Study of magnetic levitation technique applied to steel plate production line, Transactions of the IEEE on magnetics, Vol.36, No.5 (2000), pp.3686-3689.

Namerikawa, T., Mizutani, D. and Kuroki, S., Robust Hœ DIA control of levitated steel plates, IEEJ Transactions on Industry Applications, Vol.126, No.10 (2006), pp.1319-1324.

Narita, T., Hasegawa, S. and Oshinoya, Y., Hybrid electromagnetic levitation system for thin steel plates using permanent magnets, Journal of the Magnetics Society of Japan, Vol.37, No.2 (2013), pp.29-34 (in Japanese).

Ohji, T., Miao, Z., Takami, N., Amei, K and Sakui, M., Magnetic pole arrangement in a linear induction type magnetic levitation conveyer system by ac ampere force and levitation characteristics of an aluminum thin plate, Transactions of the JSAEM, Vol.19, No.3 (2011), pp.550-556 (in Japanese).

Oshinoya, Y. and Ishibashi, K., Development of electromagnetic levitation control device for a rectangular sheet steel, Transactions of the Japan Society of Mechanical Engineers, Series C, Vol.67, No.661 (2001), pp.2855-2862 (in Japanese).

Oshinoya, Y. and Kobayashi, S., Noncontact supported control for a plate with free edges, The 71st JSME spring annual meeting, (1994), pp.578-580 (in Japanese).

Oshinoya, Y., Ishibashi, K. and Sekihara, T., Conveyance control for an electromagnetic levitation rectangular sheet steel (Proposition of noncontact control mechanism for the horizontal inertial force of the steel plate which suppressed the elastic vibration), Transactions of the Japan Society of Mechanical Engineers, Series C, Vol.68, No.669 (2002), pp.1428-1434 (in Japanese).

Oshinoya, Y., Kobayashi, S. and Tanno, K., Optimal electromagnetic levitation control of a thin rectangular steel plate with two opposite edges reinforced by a beam, Transactions of the Japan Society of Mechanical Engineers, Series C, Vol.62, No.600 (1996), pp.3067-3073 (in Japanese).

Sato, K. and Torii, S., Sensorless support control of thin-steel-palate using the real-time vibration analysis technique, IEEJ Transactions on Industry Applications, Vol.128, No.3 (2008), pp.267-273 (in Japanese).

Syadanhoujin Dobokugakkai, Kouzourikigaku koushikimondaisyuu (1986), p.156 (in Japanese).

Syadanhoujin Nihonkikaigakkai, Shingijyutsuyuugou series dai 1kan jikijikuuke no kiso to ouyou (1995), pp.24-29 (in Japanese). 